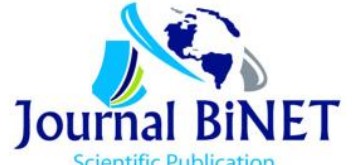

Scientific Publication
Vol. 07, Issue 01: 583-589

Journal of Bioscience and Agriculture Research

Home page: www.journalbinet.com/jbar-journal.html

\title{
Flowering, fruiting and seed maturity of common plantation tree species in Bangladesh
}

\author{
G. N. Tanjina Hasnat, M. Kamal Hossain and M. Akhter Hossain
}

Institute of Forestry and Environmental Sciences, University of Chittagong, Chittagong, Bangladesh

\begin{abstract}
Flowering, fruiting and seed maturity are important aspects in the life span of a plant or plant community. These phenological characteristics have great significance in plantation program. $A$ study was carried out from January, 2011 to March, 2012 with a view to explore these phenological affairs of 65 commercially important plantation tree species. The research was conducted covering wide area of hill forest and plain land Sal forests of Bangladesh through repeated field visits and review of literature. The results showed that flowering, fruiting and seed maturity period varied from species to species The findings of the study represent that most of the studied species bear flowers (32 - 33 species) and fruits (26 - 29 species) during March-May and April-June respectively. The flowering period varied from 3 to 5 months among the species. The results also showed that viable recalcitrant seeds of most of the species can be collected between May and June with, while for very few species seeds can be collected between September and October. The findings will be helpful to the nursery owners, small scale planters and forest managers to know the information of fruit setting and time of seed collection for raising nursery with desired plant species.
\end{abstract}

Key words: Phenology, tree species, flowering, fruiting and seed collection

\footnotetext{
Please cite this article as: Hasnat, G. N. T., Hossain, M. K. \& Hossain, M. A. (2016). Flowering, fruiting and seed maturity of common plantation tree species in Bangladesh. Journal of Bioscience and Agriculture Research 07(01), 583-589.
}

This article is distributed under terms of a Creative Common Attribution 4.0 International License.

\section{Introduction}

Plantation forests were initiated because of the gradual loss of natural forest as establishment of plantation would cover the deforested area as well as reduce or eliminate the need to exploit the natural forest. Reforestation through plantation requires a constant supply of high quality seeds (Owens, 1994). Seeds are produced through plant physiological process maintaining a complicated series of flowering, fruiting, and finally seed development and maturity. Phenology is the calendar of events in the life history of plants. The Swedish Botanist Carolus Linnaeus systematically recorded flowering times for 18 locations in Sweden over many years (NEON, 2015). Plant phenological study has great significance because it not only provides knowledge about plant growth but also supportive to the afforestation programs (Nath, 2012). 
Collection of mature and healthy seeds from disinfected, vigor, healthy and disease free mother plants is essential for raising good quality seedlings. Recalcitrant seeds loss their viability soon after their maturity. So, it requires for the collector to determine when seeds are matured and time of harvest accordingly (Beniwal, 1987). The interval between bud formation and maturity of seeds and fruits varies greatly. Many trees (for example, Acacia spp., Cassia spp.) shed their seeds within weeks of maturity, while others retain fruits and seeds for months (for example, Delonix regia) or years (for example, Eucalyptus). In most of the species, flowering and fruiting occur during definite time of the year in Bangladesh. Again this period vary within species from place to place (Ng and Loh, 1974). Many species have similar phenological pattern. Most species flower during the dry season and fruits mature just before or during the early part of the rainy season (Schmidt, 2000). The phenology of some of the tree species in Tankawati natural forest of Chittagong south forest division was studied by Motaleb and Hossain (2010). Research based report and literature on phenology of the plantation tree species in respect of Bangladesh are available only for few specific species. The flowering, fruiting and seed collection time along with morphological characteristics and germination of several species was reported by Sheikh and Matin (2007), Alam et al. (2005) and Hasan (1971). It is necessary to have a research based phenological chart which will inform the foresters about time of fruiting and seed maturity as well as guide them to collect desired seeds at right course of time. The significance of having detail phenological information motivated to conduct the study on time of flowering, fruiting and seed maturity of plantation tree species in Bangladesh. Therefore, this study will give a brief index on flowering, fruiting and seed maturity of 65 common plantation tree species in Bangladesh.

\section{Materials and Methods}

The study was carried out throughout the country generally on plantation sites, mostly covered Jessore, Jhenidah, Kushtia, Rajshahi, Mymensingh, Tangail, Sylhet and Chittagong districts of Bangladesh from January, 2011 to March, 2012. A total of 65 plantation tree species belonging to 45 genera and 23 families were selected considering their uses in plantation program. Tree species composition of different natural forests reported by Alam et al. (1995), Dutta et al. (2014), Hossain et al. (2013), Hossain and Hossain (2014) and Uddin et al. (2010) were reviewed to verify the targeted species from different natural forests. The selected trees for each species were then observed in the field during the study periods. Frequent field visit were made on the same forests to observe the changes in phenological affairs of the plants. Sometimes data on phenological affairs were collected from field guides when field visits could not be made.

The periods of flowering, fruiting and seed collection were observed at different places for each species. The recorded data were then verified with the existing reports (Beniwal, 1987; Motaleb and Hossain, 2010; Hasan, 1971; Hossain and Ahmed, 2008; Ghazali and Rahim, 1985; Heining, 1925; Khan, 1958; Brandis, 1906) and finally listed down (Table 01). For graphical presentation the findings are arranged with their flowering, fruiting and seed maturity period.

\section{Results and Discussion}

The study revealed that the selected 65 plant species produce flowers, fruits and seeds round the year. Each of the 65 plant species produces flowers once in a year except Acacia nilotica, which flower twice a year. Flowering, fruiting and seed collection time of each of the 65 species were represented in Table 01.

Flowering period of the observed 65 plant species revealed that most of the plant species $(33$ species, $50.8 \%$ of 65 species) bloomed in March followed by April (32 species, 49.2\% of 65 species) and May (29 species, $44.6 \%$ of 65 species) (Figure 01). The figure showed that the peak flowering time for most of the species was March and May depending on site and climatic condition. Very few plants were found to bloom during the months of August to December. Longest flowering period was observed in Cassia fistula (April to September) whereas lowest flowering period was found in 30 species. Lowest flowering period varied from one to two months. Moreover, flowering period of 25 species were observed 3 months followed by 5 species for 4 months and 3 species for 5 months. The flowering 
periods for most of the species were similar to the reports of Yap (1982) who found most of the flowering tree species of lowland dipterocarp forest of Malaysia bear flowers in February to March.

Table 01. Flowering, fruiting and seed collection time of 65 plantation tree species

\begin{tabular}{|c|c|c|c|c|c|c|}
\hline $\begin{array}{l}\text { Sl. } \\
\text { no. }\end{array}$ & Scientific name & Local name & Family & $\begin{array}{l}\text { Flowering } \\
\text { period }\end{array}$ & $\begin{array}{l}\text { Fruiting } \\
\text { period }\end{array}$ & $\begin{array}{l}\text { Seed } \\
\text { collection } \\
\text { time }\end{array}$ \\
\hline 1 & Acacia auriculiformis & Akashmoni & Mimosaceae & Dec-Jan & Feb-Mar & Jan-Mar \\
\hline 2 & Acacia catechu & Khair & Mimosaceae & Apr-May & June-July & Aug-Sep \\
\hline 3 & Acacia hybrid & Hybrid acacia & Mimosaceae & Jan-Feb & Feb-Mar & Mar-Apr \\
\hline 4 & Acacia nilotica & Babla & Mimosaceae & $\begin{array}{l}\text { Jun-Sep \& } \\
\text { Dec-Jan }\end{array}$ & $\begin{array}{l}\text { Feb-Apr \& } \\
\text { Jul-Oct }\end{array}$ & $\begin{array}{l}\text { Mar-May } \\
\text { \& Oct-Jan }\end{array}$ \\
\hline 5 & Adina cordifolia & Haldu & Rubiaceae & Mar-Jul & Sep-Oct & Feb-Mar \\
\hline 6 & Albizia chinensis & Tetuyakoroi & Mimosaceae & May-Jun & Aug-Jan & Feb-Mar \\
\hline 7 & Albizia lebbeck & Kalokoroi & Mimosaceae & Mar-Jul & Aug-Nov & Dec-Jan \\
\hline 8 & Albizia odoratissima & Chakuakoroi & Mimosaceae & Apr-Jun & Sep-Dec & Feb-Mar \\
\hline 9 & Albizia procera & Silkoroi & Mimosaceae & Sep-Oct & Nov-Feb & Feb-Mar \\
\hline 10 & Albizia saman & Randikoroi & Mimosa & Iay-Jun & Mar & Mar-Apr \\
\hline 11 & Anisoptera scaphula & Boilam & Dipterocarpaceae & Dec-Jan & Mar-Apr & Apr-Jun \\
\hline 12 & Aphanamixis polystachya & Pitraj & Meliaceae & Oct-Nov & Feb-Mar & Mar-Apr \\
\hline 13 & Anthocephalus chinensis & $\mathrm{Kad}$ & Rubiaceae & $\mathrm{n}$ & Jun & Sep-Oct \\
\hline 14 & Artocarpus chaplasha & Cha & Mora & & $\mathrm{Ma}$ & Jul-Aug \\
\hline 15 & s heterophyllus & $\mathrm{Ka}$ & Mo & & & $-\mathrm{Jul}$ \\
\hline 16 & cucha & $\mathrm{Ba}$ & e & & & Sep \\
\hline 17 & Cass & So & hiaceae & & & Dec \\
\hline 18 & Dalb & Sis & Mir & ar & ug & $\mathrm{Feb}$ \\
\hline 19 & Delon & Kris & piniaceae & pr & $\mathrm{Ap}$ & May-Jun \\
\hline 20 & pus costatus & Bai & $\mathrm{Di}$ & $\mathrm{b}$ & ay & Jun-Jul \\
\hline 21 & pus gracilis & Dhu & Dipt & $\operatorname{ar}$ & $\mathrm{pr}$ & May-Jun \\
\hline 22 & Dipterocarpus turbinatus & Tel & Dipt & $r$ & Iay & May-Jun \\
\hline 23 & Duabanga grandiflora & Ban & Sor & $\mathrm{ar}$ & $\mathrm{pr}$ & Apr-May \\
\hline 24 & s tectorius & & ae & & & -Nov \\
\hline 25 & a limonia & Kotbel & Rut & $\mathrm{M}$ & ov & -Jan \\
\hline 26 & enghalensis & Bot & ae & un & Jun & Aug \\
\hline 27 & Gliric & Gliricidia & ae & $\operatorname{ar}$ & May & Apr-May \\
\hline 28 & Gme & G & ceae & & ay & May-Jul \\
\hline 29 & ensis & $\mathrm{R}$ & ae & $\mathrm{n}$ & & Sep \\
\hline 30 & Hopea odorata & Telsur & Dipterocarpaceae & $\mathrm{pr}$ & Iay & May-Jun \\
\hline 31 & етіa macrocarpa & Ban & Lytl & $\begin{array}{l}\text { Not on } \\
\text { record }\end{array}$ & $\begin{array}{l}\text { Not on } \\
\text { record }\end{array}$ & Aug - Sep \\
\hline 32 & Las & Sidl & & $\Delta n r-$ & Sep-Ian & \\
\hline 33 & $L a$ & ajaru & Lyth & Apr-Jun & Jov & Nov-Jan \\
\hline 32 & phala & Ipi & nosae & $\mathrm{Ma}$ & $\mathrm{DV}$ & Feb \\
\hline 35 & s acuminata & Kal & ae & ar & $\mathrm{Fe}$ & May-Nov \\
\hline 36 & s elegans & Talb & Fag & $\mathrm{pr}$ & ep & May-Oct \\
\hline 37 & is pachyphylla & Kantabatna & Fagaceae & Feb-Apr & Mar-Aug & Jul-Oct \\
\hline 38 & s polystachya & Sadabatna & Fagaceae & Nov-Feb & Jan-Jun & Apr-Jul \\
\hline 39 & longifolia & Mohua & ceae & Mar-May & Apr-Jun & May-Jul \\
\hline 40 & Mangi & $\mathrm{Am}$ & diace & Jan-Mar & Apr-May & May-Jun \\
\hline 41 & Man & Saf & Sapolaced & $\begin{array}{l}\text { Year } \\
\text { round }\end{array}$ & $\begin{array}{l}\text { Year } \\
\text { round }\end{array}$ & $\begin{array}{l}\text { Year } \\
\text { round }\end{array}$ \\
\hline 42 & $M$ & Melale & Mv & May-Ju & Jun-Aug & Aug-Sep \\
\hline 43 & rvirens & & & Иay & Apr-Jul & Jun-Sep \\
\hline 44 & Mest & hwar & eae & $\mathrm{M}$ & Jul- & Aug-Sep \\
\hline 45 & Mimusops elengi & Bokul & Sapotaceae & Mar-Jun & Apr-Aug & Aug-Sep \\
\hline 46 & Oroxylum indicum & Kanaidingi & Bignoniaceae & May-Aug & Jul-Sep & Feb-May \\
\hline 47 & Pterocarpus dalbergioides & Paduak & Fabaceae & Mar-Apr & Apr-Jun & May-Jun \\
\hline 48 & Schima wallichii & Kanak & Theaceae & Apr-May & Jun-Aug & Oct-Nov \\
\hline 49 & Shorea robusta & Sal & Dipterocarpaceae & Feb-Apr & Apr-May & May-Jun \\
\hline
\end{tabular}




\begin{tabular}{|c|c|c|c|c|c|}
\hline Sonneratia apetala & Keora & Sonneratiaceae & Apr-Jun & Jun-Jul & Jul-Sep \\
\hline Stereospermum colais & Dharmara & Bignoniaceae & May-Jul & Aug-Jan & Feb-Apr \\
\hline Stereospermum suaveolens & Parul & Bignoniaceae & Mar-Apr & Apr-May & May-Jun \\
\hline Swietenia mahagoni & Mahagoni & Meliaceae & Apr-May & May-Dec & Jan-Feb \\
\hline Syzygium cumini & Kalojam & Myrtaceae & Feb-Mar & Apr-May & Jun-Jul \\
\hline Syzygium fruticosum & Putijam & Myrtaceae & Mar-Apr & Apr-May & May-Jun \\
\hline Syzygium grandis & Dhakijam & Myrtaceae & Feb-Mar & Mar-Apr & May-Jun \\
\hline Swintonia floribunda & Civit & Anacardiaceae & Jan-Mar & Mar-Apr & Apr-May \\
\hline Tamarindus indica & Tentul & Caesalpiniaceae & Apr-Jun & Aug-Oct & Jan-Mar \\
\hline Tectona grandis & Shegun & Verbenaceae & Aug-Sep & Oct-Nov & Dec-Feb \\
\hline Terminalia bellirica & Bohera & Combretaceae & Mar-May & Aug-Dec & Jan-Feb \\
\hline Terminalia chebula & Haritoki & Combretaceae & Apr-May & Sep-Mar & Mar-Apr \\
\hline Toona cilita & Toon & Meliaceae & Mar-Apr & May-Jun & May-Jul \\
\hline Trewa nudiflora & Pitali & Euphorbiaceae & Jan-Mar & Apr-Jun & Jun-Jul \\
\hline Ziziphus mauritiana & Boroi & Rhamnaceae & Sep-Nov & Nov-Jan & Jan-Mar \\
\hline 65 Xylia xylocarpa & Lohakat & Mimosaceae & Mar-Apr & Dec-Jan & Mar-Apr \\
\hline
\end{tabular}

The field observation revealed that April is the noticeable fruiting time as most of the species (29 species) bear fruits at this time. In May, a total of 26 species was observed to bear fruits followed by June, the third most peak fruiting period. The lowest fruiting time was checked up in November i.e. 9 species produced fruits (Figure 02). Manilkara zapota was found to bear fruits almost throughout the year. Lithocarpus acuminata bear fruits for maximum period ( 9 months) extending from February to October. Moreover, duration of fruiting was also higher for Swietenia mahagoni (8 months) followed by Lithocarpus elegans ( 7 months) and 6 months for Terminalia chebula, Albizia chinensis, Lithocarpus polystachya, Lithocarpus pachyphylla and Stereospermum colais.

Seed collection time comes after fruit maturity when fruit ripe and become suitable for harvesting. Generally seeds are collected from a tree when most of the seeds become suitable for collection. This peak period of maturity may be considered for future seed collection. Period of seeds retained in trees after fruit maturity varies between species. The results showed that the seed collection time was between May and June for most of the studied species with seed viability and can be sown immediately, while very few species were found to have seed collection time between September and October (Figure 02). Seeds collected at that time need to be stored for propagation in the next year. Motaleb and Hossain (2010) reported that most of the fruits and seeds become available for collection in May to September. Schmidt (2000) represented seed collection time of a number of tropical and subtropical species which is also comparable to the present study. Hasan (1971) reported that seeds of most of the tree species may be collected during May to June.

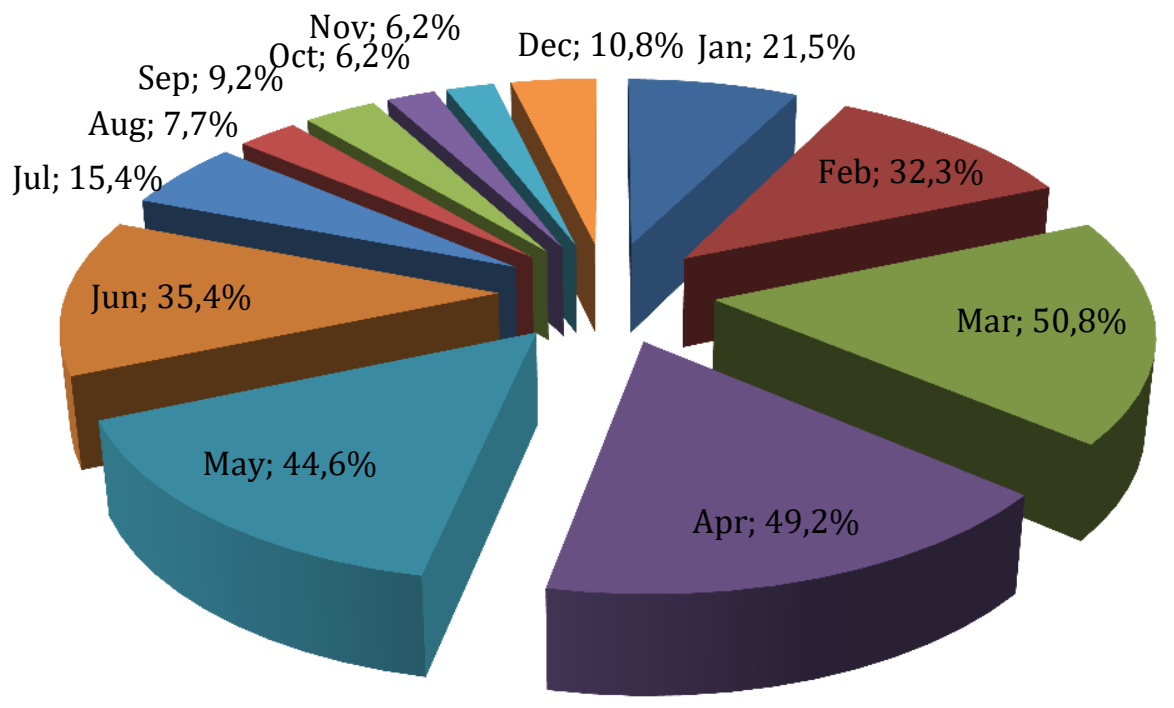

Figure 01. Month wise peak flowering intensity (\%) of the 65 major plantation species. 


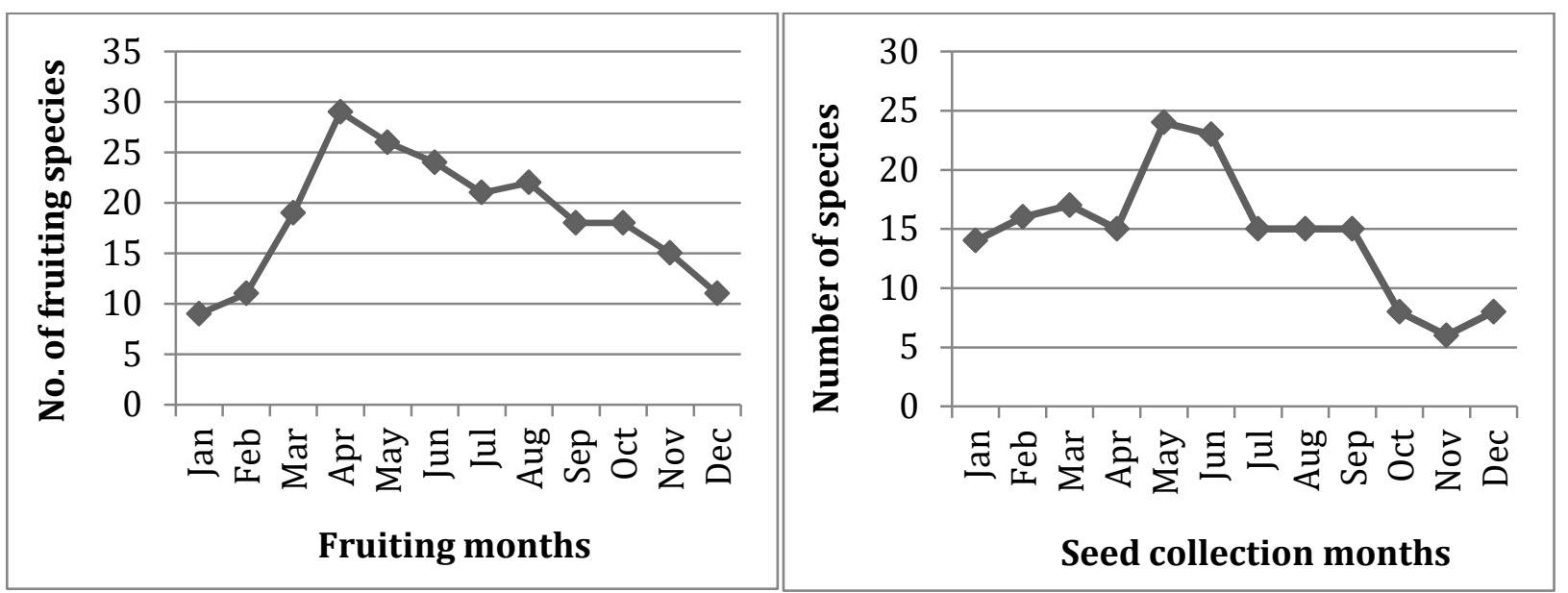

Figure 02. Month wise peak fruiting intensity (left) and seed collection time (right) of the 65 major plantation species

Seed is the most important productive part for introducing a plant in any area through establishing plantation. Production of seeds in sufficient quantities will go in vain if plant propagators do not know the seed collection time of desired species. So, knowing of flowering, fruiting and seed maturity time is the prior factor in the seed collection. A number of species take a longer time for fruit maturity and also contain viability but there are also some low viability seeds which mainly belong to Dipterocarpus spp., Syzygium spp. and Swintonia floribunda (Beniwal, 1987; Hasan, 1971; Ng and Loh, 1974). For raising nursery with future seed source fruits need to be collected as soon as they fall and should be immediately planted in a nursery (Ghazali and Rahim, 1985) or proper restoration site. For this purpose flowering, fruiting and seed collection times are of prime need in any sense (Beniwal, 1987). Results of this study is in line with the published reports of Hossain and Ahmed (2008), Schmidt and Jøker (2000), Malik et al. (2010), Benthal (1933) and NAS (1979) who studied on single or a few species along with seed biology. The findings of the study provide a crystal idea about the species wise phenological response which will be supportive for quality seed supply and raising plantations.

\section{Conclusion}

The present study provides information on flowering, fruiting and seed collection time for 65 commercially important plant species. The nursery owners, forest managers and small scale planters proceed with seed collection program each year. The findings will be helpful to those stakeholders informing them about right time of seed collection of important plantation species in Bangladesh. The studied phenological affairs of the 65 tree species will help to elucidate the future changes in relation to climate change and other environmental stresses

\section{Reference}

[1]. Alam, M. A., Matin, M. A., Hoque, M. M. \& Hoque, A. T. M. R. (2005). Seed morphology and germination of ipil-ipil (Leucaena leucocephala (Lam.) De. Wit.) under different condition at nursery stage in Bangladesh. Asian Journal of Plant Sciences, 4(2), 98-101. http://dx.doi.org/10.3923/ajps.2005.98.101

[2]. Beniwal, B. S. (1987). Phenological study of trees in Arunachal Pradesh, India. The Indian Forester, 113, 779.

[3]. Benthal, A. P. (1933). The trees of Calcutta and its neighborhood. Calcutta, Thacker spink and company limited, London. p. 140.

[4]. Brandis, D. (1906). Indian trees. International book distributor, Dehradun. p. 214.

[5]. Dutta, S., Hossain, M. K., Hossain, M. A. \& Chowdhury, P. (2014). Floral diversity of Sitakunda Botanical Garden and Ecopark in Chittagong, Bangladesh. Indian Journal of Tropical Biodiversity, 22(2), 106-118. 
[6]. Ghazali, M. \& Rahim, A. (1985). Flowering to fruiting period of Malaysian forest trees. The Malaysian Forester, 48(3), 254.

[7]. Hasan, S. M. (1971). Problems of seed supply for the plantation program in Bangladesh. Forest Dale News, 4(1), 8.

[8]. Heining, R. L. (1925). List of the plants of Chittagong Collectorate and Hill Tracts. pp. 84.

[9]. Hossain, M. A., Hossain, M. K., Salam M.A. \& Rahman S. (2013). Composition and Diversity of Tree Species in Dudhpukuria-Dhopachori Wildlife Sanctuary of Chittagong (South) Forest Division, Bangladesh. Research Journal of Pharmaceutical, Biological and Chemical Science, 4(2), 1447-1457.

[10]. Hossain, M. K. \& Ahmed, F. U. (2008). Biponnoprai Brikkha Projatir Nursery Manual, Published by Arannayk Foundation, Banani, Dhaka-1213, Bangladesh. p. 95. (Bengali version).

[11]. Hossain, M. K. \& Hossain, M. A. (2014). Biodiversity of Chunati Wildlife Sanctuary: Flora, Arannayk Foundation and Bangladesh Forest Department, Dhaka, Bangladesh. p. iv, 176.

[12]. http://budburst.org/ phenology_history.

[13]. Khan, H. A. (1958). Acacia in Pakistan. Pakistan Forest College and Research Institute, Abbotabad. p. 30.

[14]. Malik, S. K., Chaudhury, R., Dhariwal, O. P. \& Bhandari, D. C. (2010). Genetic resources of tropical underutilized fruits in India. NBPGR, New Delhi. p. 168.

[15]. Motaleb, M. A. \& Hossain, M. K. (2010). Phenology of native tree species of Tankawati natural forest, Chittagong (south) forest division, Bangladesh. Indian journal tropical Biodiversity, 18(1), 67.

[16]. NAS (National Academy of Science). (1979). Tropical legumes: resources for the future. National Academy of Science, Washington D.C. p. 331.

[17]. Nath, N. (2012). Phenological study of some tree species of Sri Surya pahar of Goalpara district, Assam. Indian Journal of Fundamental and Applied Life Sciences, 2(1), 102-104.

[18]. NEON (National Ecological Observatory Network), 2015. Science History. In: Project Budburst. National Ecological Observatory Network and the Chicago Botanic Garden,

[19]. Ng, F. S. P. \& Loh, H. S. (1974). Flowering to fruiting periods of Malaysian trees. The Malaysian Forester, 37(2), 127.

[20]. Owens, J. N. (1994). Constraints to seed production: temperate and tropical forest trees. Tree Physiology, 15, 477. http://dx.doi.org/10.1093/treephys/15.7-8.477

[21]. Schmidt, L. \& Jøker, D. (2000). Seed leaflet: Swietenia mahagoni (L.) Jacq. [www.dfsc.dk]

[22]. Schmidt, L. (2000). Guide to Handling Tropical and Subtropical Forest Seed. Danida Forest Seed Center, Krogerupvej 21, DK - 3050 Humleback, Denmark. p. 510.

[23]. Sheikh, A. H. \& Matin, M. A. (2007). Seed morphology and germination studies of Dalbergia sissoo Roxb. at nursery stage in Bangladesh. Research Journal of Agriculture and Biological Sciences, 3(1), 35.

[24]. Uddin, M. Z. \& M. A. Hassan. (2010). A preliminary assessment of angiosperm diversity of Lawachara national park (Bangladesh). Bangladesh Journal of Plant Taxonomy, 17(1), 9-22. http://dx.doi.org/10.3329/bjpt.v17i1.5387

[25]. Yap, S. K. (1982). The phenology of some fruit tree species in a lowland Dipterocarp forest. The Malaysian Forester, 45(1), 21. 


\section{How to cite this article?}

Citation for this article (APA Style):

Hasnat, G. N. T., Hossain, M. K. \& Hossain, M. A. (2016). Flowering, fruiting and seed maturity of common plantation tree species in Bangladesh. Journal of Bioscience and Agriculture Research, 07(01), 583-589.

\section{MLA (Modern Language Association)}

Hasnat, G. N. T., Hossain, M. K. \& Hossain, M. A. "Flowering, fruiting and seed maturity of common plantation tree species in Bangladesh." Journal of Bioscience and Agriculture Research, 07. 01 (2016): 583-589.

\section{Chicago/Turabian}

Hasnat, G. N. T., Hossain, M. K. \& Hossain, M. A. "Flowering, fruiting and seed maturity of common plantation tree species in Bangladesh." Journal of Bioscience and Agriculture Research, 07, no. 01 (2016): 583-589.

Submit article and publish with Journal BiNET.

\section{Key Features:}

$\checkmark \quad$ Faster processing and review of article

$\checkmark \quad$ Quick review and editorial tasks

$\checkmark \quad$ International editorial and review board

$\checkmark \quad 21$ business day's rapid publication

$\checkmark \quad$ View and read articles powered by Scribd

$\checkmark \quad$ Greater audience readership is ensured for all article

$\checkmark \quad$ Indexing and bibliographic integration of article

$\checkmark \quad$ Social sharing enabled article

Submit article (or email to submit@ journalbinet.com): http://www.journalbinet.com/article-submission-form.html 